\title{
DIGLOSIA
}

Volume 2, Nomor 2 (Agustus 2019)

p-ISSN 2615-725X (Print)

Halaman 93-102

e-ISSN 2615-8655 (Online)

\section{PENGEMBANGAN BAHAN AJAR MENULIS CERPEN BERBASIS PENGALAMAN SISWA KELAS XI SMK}

\author{
Veronika Hanyaq Himang, ${ }^{1, *}$, Widyatmike Gede Mulawarman ${ }^{2}$, dan M Ilyas ${ }^{3}$ \\ ${ }^{1}$ Magister Pendidikan Bahasa dan Sastra Indonesia, FKIP, Universitas Mulawarman \\ ${ }^{2,3}$ Fakultas Keguruan dan Ilmu Pendidikan, Universitas Mulawarman \\ ${ }^{1, *}$ Pos-el Korespondensi: veronika.hanyaq92@gmail.com \\ ${ }^{2}$ Pos-el: widyatmikegedemulawarman@yahoo.co.id \\ ${ }^{3}$ Pos-el: milyas1010@gmail.com
}

\begin{abstract}
This research has some purposes: (1) describing the design for development of teaching materials for writing short story based on students' experience, (2) describing the learning implementation of writing short story based on students' experience, and (3) measuring the quality of teaching materials for writing short story based on students' experience which is marked from validity, practicality, and effectivity. This research uses research and development method adapted from ten development methods by Borg \& Gall consist of necessary analysis, plan, product initial draft organization, product design validity test, product design revision, trial I, product revision II, trial II, final product revision, and dissemination and implementation. The developed teaching materials quality could be seen from the validity test result which shows $90 \%$ as the material score, $88 \%$ as language score, $89 \%$ as presentation score, and $90 \%$ as graphics score which result $90 \%$ as the average value that means very valid criteria. The result of practicality test could be seen from the score of RPP (lesson plan) implementation which shows 92\%, teachers' response score which shows 89\%, and students' response score which shows $87 \%$ that result $89 \%$ as the average value which means very practical criteria. The result of effectivity test could be seen from teachers' activity score which shows 93\%, students' activity score which shows $92 \%$, and the result of students' short story writing which shows $81 \%$ that result $89 \%$ as the average that means very effective criteria. Therefore, the researcher concludes the result for development of teaching materials for writing short story based on vocational high school (SMK) students' experience is stated very valid, very practical, and very effective for used as teaching materials for writing short story based on vocational high school (SMK) grade XI students' experience.
\end{abstract}

Keywords: teaching materials; short story writing; experiential learning

\begin{abstract}
ABSTRAK
Penelitian ini bertujuan untuk: (1) mendeskripsikan desain pengembangan bahan ajar menulis cerpen berbasis pengalaman, (2) mendeskripsikan pelaksanaan pembelajaran menulis cerpen berbasis pengalaman, dan (3) mengukur kualitas bahan ajar menulis cerpen berbasis pengalaman yang dinilai dari kevalidan, kepraktisan, dan keefektifannya. Penelitian ini menggunakan metode penelitian dan pengembangan yang diadaptasi dari sepuluh model pengembangan Borg \& Gall, yaitu analisis kebutuhan dan kajian pustaka, perencanaan, penyusunan draf awal produk, uji validasi desain produk, revisi desain produk, uji coba I, revisi produk II, uji coba II, revisi produk akhir, dan diseminasi dan implementasi. Kualitas bahan ajar yang dikembangkan dapat dilihat dari hasil uji validasi, yakni nilai materi $90 \%$, nilai bahasa $88 \%$, nilai sajian $89 \%$, dan nilai grafika $90 \%$ yang diperoleh hasil rata-rata $90 \%$ dengan
\end{abstract}


kriteria sangat valid. Hasil uji kepraktisan dilihat dari nilai keterlaksanaan RPP 92\%, nilai respons guru $89 \%$, nilai respons siswa $87 \%$ yang diperoleh hasil rata-rata $89 \%$ dengan kriteria sangat praktis. Hasil uji keefektifan dilihat dari nilai aktivitas guru 93\%, nilai aktivitas siswa $92 \%$, dan hasil menulis cerpen siswa $81 \%$ yang diperoleh hasil rata-rata $89 \%$ dengan kriteria sangat efektif. Dengan demikian, disimpulkan bahwa hasil penelitian pengembangan bahan ajar menulis cerpen berbasis pengalaman siswa Kelas XI SMK ini dinyatakan sangat valid, sangat praktis, dan sangat efektif digunakan sebagai bahan ajar menulis cerpen siswa kelas XI SMK.

Kata kunci: bahan ajar; menulis cerpen; experiential learning

\section{A. PENDAHULUAN}

Pengembangan pendidikan dapat dilakukan dalam semua aspek pendidikan untuk meningkatkan mutu pendidikan di Indonesia. Salah satu penelitian yang efektif, yaitu dengan penelitian pengembangan (research and development). Sugiyono (2017:28) menjelaskan penelitian dan pengembangan berfungsi untuk memvalidasi dan mengembangkan produk. Berdasarkan hasil studi pendahuluan yang dilakukan di lokasi penelitian, yaitu SMK Negeri 12 Samarinda, ditemukan masalah bahwa keterampilan dan minat menulis siswa masih kurang. Siswa kesulitan ketika menemukan ide cerita dan mengembangkan ide cerita dan guru yang mengajar masih menggunakan metode ceramah. Selain itu, perubahan peraturan tidak diimbangi ketersediaan buku ajar. Keseluruhan isi buku yang digunakan sudah baik namun lebih banyak berisi materi pembelajaran dan tugas tetapi belum dijelaskan secara rinci dan mendalam tentang langkah-langkah dalam menulis cerpen.

Maka dipilih model pembelajaran berbasis pengalaman (exsperiential learning) ini didasarkan pada kesesuaian model pembelajaran ini dengan materi pembelajaran menulis cerpen dan model ini belum pernah digunakan oleh guru dalam pengajaran menulis cerpen di SMK Negeri 12 Samarinda, tempat penulis melakukan penelitian. Keunggulan dari model pembelajaran ini adalah hasil dapat dirasakan bahwa pembelajaran lewat pengalaman lebih efektif dan mencapai tujuan secara maksimal. Buku yang dikembangkan diharapkan dapat meningkatkan kemampuan siswa dalam menulis cerpen dan membantu guru dalam mengelola pembelajaran yang praktis, efektif, serta dapat menjadi referensi dalam menyampaikan materi pelajaran menulis cerpen.

Penelitian tentang menulis cerpen pernah dilakukan oleh Ana Masruroh tahun 2015 yang berjudul Pengembangan Modul Pembelajaran Menulis Cerpen Berbasis Pengalaman (Experiential Learning) untuk Siswa SMP/MTs. Dalam penelitian tersebut ditemukan sebagian besar siswa kesulitan dalam menulis cerpen, khususnya dalam hal mencari dan mengembangkan ide. Selain itu, siswa hanya menggunakan satu buku saja untuk pembelajaran tanpa adanya buku panduan yang lain seperti LKS, modul pembelajaran, dan lain-lain. Persamaan penelitian tersebut dengan penelitian yang penulis lakukan adalah sama-sama mengembangkan bahan ajar berbasis pengalaman namun dalam penelitian ini, penulis lebih memfokuskan pengalaman siswa dengan menggali nilai-nilai kearifan lokal masyarakat.

\section{B. LANDASAN TEORI}

\section{Penelitian Pengembangan}

Pengertian penelitian dan pengembangan menurut Borg \& Gall (dalam Sugiyono, 2017:28) merupakan 
proses/metode yang digunakan dan memvalidasi suatu produk. Ditambahkan oleh Seals \& Richey (dalam Sugiyono, 2017:28-29) bahwa dalam bidang pembelajaran, penelitian ini sekarang dinamakan Design and Development Research. Sebelumnya dinamakan developmental research. Perancangan dan penelitian pengembangan adalah kajian yang sistematis tentang membuat rancangan suatu mengembangkan/memproduksi produk, rancangan tersebut, dan mengevaluasi kinerja produk tersebut. Bahan ajar yang dikembangkan dalam penelitian ini adalah bahan ajar menulis cerpen dengan menerapkan model pembelajaran berbasis pengalaman (experiential learning).

\section{Bahan Ajar}

Prastowo (2011:16) menyatakan bahwa bahan ajar adalah seperangkat materi yang disusun secara sistematis, baik tertulis maupun tidak tertulis, sehingga tercipta lingkungan dan suasana yang memungkinkan peserta didik untuk belajar. Daryanto \& Cahyono (2014:171) juga menyatakan bahwa bahan ajar adalah seperangkat materi yang disusun secara sistematis baik tertulis maupun tidak sehingga tercipta lingkungan/suasana yang memungkinkan siswa untuk belajar.

Lebih lanjut, Majid (2013:173) berpendapat bahwa bahan ajar adalah segala bentuk bahan yang digunakan untuk membantu guru/instruktur dalam melaksanakan kegiatan belajar mengajar. Ditambahkan oleh Widodo \& Jasmadi (dalam Lestari, 2013:1) bahwa bahan ajar adalah seperangkat sarana atau alat pembelajaran yang berisikan materi pembelajaran, metode, batasan-batasan, dan cara mengevaluasi yang didesain secara sistematis dan menarik dalam rangka mencapai tujuan yang diharapkan, yaitu mencapai kompetensi atau subkompetensi dengan segala kompleksitasnya.
Berdasarkan beberapa pendapat tersebut, dapat disimpulkan bahwa bahan ajar adalah seperangkat sarana atau alat pembelajaran yang berisi materi pembelajaran, metode, batasan-batasan, dan cara mengevaluasi yang didesain dan disusun secara sistematis baik tertulis atau tidak untuk membantu guru dan siswa dalam proses pembelajaran sehingga memungkinkan terciptanya suasana belajar yang menarik dan menyenangkan.

Terdapat berbagai jenis bahan ajar. Ada yang berbentuk buku, modul, maupun bahan ajar yang berbasis komputer. Bahan ajar noncetak, meliputi bahan ajar dengar (audio) seperti kaset, radio, piringan hitam, dan compact disc audio. Bahan ajar pandang dengar (audio visual) seperti video compact disc dan film. Bahan ajar multimedia interaktif (interactive teaching material), contohnya compact disk interactive.

\section{Menulis}

Tarigan (2013:22) menjelaskan bahwa menulis ialah menurunkan atau melukiskan lambang-lambang grafik yang menggambarkan suatu bahasa yang dipahami oleh seseorang, sehingga orang lain dapat membaca lambang-lambang grafik tersebut, kalau mereka memahami bahasa dan gambaran grafik itu. Gambar atau lukisan mungkin dapat menyampaikan makna-makna, tetapi tidak menggambarkan kesatuan-kesatuan bahasa. Menulis merupakan suatu representasi bagian dari kesatuan-kesatuan ekspresi bahasa. Musaba \& Siddik (2017:4 -5) menambahkan bahwa menulis berarti melahirkan atau mengungkapkan pikiran dan atau perasaan melalui suatu lambang (tulisan). Tentu saja segala lambang (tulisan) yang dipakai haruslah merupakan hasil kesepakatan para pemakai bahasa yang satu dengan lainnya saling memahami. Apabila seseorang diminta untuk menulis maka berarti ia akan mengungkapkan pikiran dan/atau perasaannya ke dalam bentuk 
tulisan. Berdasarkan pendapat-pendapat tersebut, dapat disimpulkan bahwa menulis adalah kegiatan menurunkan atau mengungkapkan pikiran dan atau perasaan melalui suatu lambang (tulisan) yang telah disepakati dan dipahami oleh para pemakai bahasa satu dengan yang lainnya.

Kegiatan menulis merupakan suatu proses. Sebagai suatu proses, menulis dilakukan secara bertahap, yaitu (a) perencanaan tulisan (prapenulisan), (b) penulisan, dan (c) revisi (Akhadiah et al, 1991:3). Nursisto (2000:56-58) menambahkan setelah kegiatan mengembangkan kerangka karangan, dilanjutkan dengan kegiatan koreksi dan revisi, kemudian menulis naskah jadi.

\section{Cerpen (Cerita Pendek)}

Menurut Edgar Allan seorang sastrawan kenamaan dari Amerika yang dikutip oleh Yassin (dalam Nurgiyantoro, 2009:10), cerpen adalah sebuah cerita yang selesai dibaca sekali duduk, kira-kira berkisar antara setengah sampai dua jam. Lebih lanjut, Muryanto (2008) menyatakan bahwa cerita pendek adalah salah satu karya sastra yang berbentuk prosa. Sesuai dengan namanya, cerpen (cerita pendek) haruslah pendek sebatas selesai baca dalam sekali duduk dan harus menimbulkan kesan selesai, tidak lagi mengusik dan menggoda karena ceritanya seperti masih berlanjut. A. Hamid menambahkan, dalam cerpen banyaknya perkataan yang dipakai antara 50020.000 kata, adanya satu plot, adanya satu watak, dan adanya satu kesan. Berdasarkan pendapat tersebut dapat disimpulkan bahwa cerpen adalah sebuah cerita yang berbentuk prosa yang selesai dibaca dalam sekali duduk dan meninggalkan kesan yang mendalam.

Tarigan (dalam Rampan, 2009:14 15) merumuskan beberapa ciri cerpen yang menunjukkan kekhasannya sebagai karya sastra. Ciri-ciri cerpen adalah (1) singkat, padu, dan intensif; (2) pengadeganan, tokoh, dan gerak; (3) bahasa yang digunakan haruslah tajam, sugestif, dan menarik perhatian; (4) interpretasi pengarang tentang konsep terhadap kehidupan, baik langsung maupun tidak langsung; (5) hanya menimbulkan satu efek saja dalam pikiran pembaca; (6) menyentuh perasaan, agar cerita menarik secara latar; (7) harus tercipta detail persoalan dan kejadian yang sudah diplot; (8) suatu kejadian harus menguasai seluruh cerita; (9) memiliki sorang tokoh utama yang menentukan; (10) memberi dampak atau kesan tertentu bagi pembaca; (11) hanya ada satu situasi, dan (12) memiliki kesan tunggal serta tidak berberaian.

Cerpen terdiri atas dua unsur, yaitu unsur intrinsik dan unsur ekstrinsik. Menurut Muryanto (2008:6), unsur intrinsik merupakan unsur yang membangun cerpen dari dalam. Saat membaca sebuah cerpen, unsur-unsur tersebut dapat kita temukan secara tersurat maupun tersirat. Unsur intrinsik cerpen berupa tema, amanat, alur dan pengaluran, tokoh dan penokohan, latar dan pelataran, sudut pandang, dan gaya bahasa. Unsur ekstrinsik adalah unsur-unsur yang berada di luar karya sastra, tetapi secara tidak langsung memengaruhi bangun cerita sebuah karya. Unsur-unsur ekstrinsik meliputi latar belakang masyarakat, biografi pengarang atau latar belakang penulis, dan nilai-nilai yang terkandung dalam cerpen.

\section{Model Pembelajaran Berbasis Pengalaman (Experiential Learning)}

Fathurrohman

(2015:128) mendefinisikan model pembelajaran berbasis pengalaman (experiential learning) ialah belajar sebagai proses mengonstruksi pengetahuan melalui transformasi pengalaman. Belajar dari pengalaman mencakup keterkaitan antara berbuat dan berpikir. Jika seseorang terlibat aktif dalam proses belajar maka orang itu akan belajar jauh lebih baik. Hal ini disebabkan dalam 
proses belajar tersebut, pembelajar secara aktif berpikir tentang apa yang dipelajari dan kemudian bagaimana menerapkan apa yang telah dipelajari dalam situasi nyata.

Experiential learning adalah proses belajar, proses perubahan yang menggunakan pengalaman sebagai media belajar atau pembelajaran bukan hanya materi yang bersumber dari buku atau pendidik. Experiential learning adalah pembelajaran yang dilakukan melalui refleksi dan juga melalui suatu proses pembuatan makna dari pengalaman langsung. Experiential learning berfokus pada proses pembelajaran untuk masingmasing individu (Fathurrohman, 2015:129).

Experiential learning adalah suatu pendekatan yang dipusatkan pada peserta didik yang dimulai dengan landasan pemikiran bahwa orang-orang belajar terbaik itu dari pengalaman dan hal ini sesuai dengan ungkapan the experience is the best teacher. Dari kedua pendapat di atas, dapat disimpulkan bahwa experiential learning adalah proses belajar yang menggunakan pengalaman sebagai media belajar atau pembelajaran yang berpusat pada siswa.

Kolb (dalam Fathurrohman, 2015:133) mengembangkan model pembelajaran experiential learning, yaitu concrete experience (pengalaman konkrit), reflective observation (pengamatan reflektif), abstract conceptualization (konseptualisasi abstrak), dan active experimentation (percobaan aktif).

\section{Rancangan Model}

Dalam model pengembangan, Borg \& Gall memuat panduan sistematika langkah-langkah yang dilakukan oleh penulis agar produk yang dirancangnya mempunyai standar kelayakan. Dengan demikian, yang diperlukan dalam pengembangan ini adalah rujukan tentang prosedur produk yang akan dikembangkan.
Sepuluh langkah dalam penelitian pendidikan dan pengembangan yang disarankan Borg \& Gall (Sugiyono, 2015:35-37), yaitu (1) research and information collecting (penelitian dan pengumpulan data), 2) planning (perencanaan), 3) develop preliminary form a product (pengembangan draf awal produk), 4) preliminary field testing (uji coba lapangan awal), 5) main product revision, 6) main field testing (revisi hasil uji coba lapangan awal), 7) operational product revision, (uji coba lapangan), 8) operational field testing (penyempurnaan hasil uji coba lapangan), 9) final product revision (penyempurnaan produk akhir), dan 10) dissemination and implementation (diseminasi dan implementasi).

\section{METODE PENELITIAN}

Penelitian ini menggunakan metode penelitian dan pengembangan atau research and development $(\mathrm{R} \& \mathrm{D})$. Menurut Borg \& Gall (dalam Sugiyono, 2017:28), penelitian pengembangan merupakan proses/ metode yang digunakan untuk memvalidasi dan mengembangkan produk. Berdasarkan pendapat tersebut, maka dapat disimpulkan bahwa penelitian dan pengembangan merupakan metode yang digunakan untuk memvalidasi dan mengembangkan produk atau menyempurnakan produk.

Penelitian pengembangan ini menggunakan sepuluh langkah metode Research and Development oleh Borg \& Gall yang disesuaikan dengan konteks dan kebutuhan pengembangan bahan ajar menulis cerpen siswa kelas XI SMK dengan model pembelajaran berbasis pengalaman (experiential learning). Sepuluh langkah dalam penelitian ini, yaitu analisis kebutuhan dan kajian pustaka, perencanaan, penyusunan draf awal produk, uji validasi desain produk, revisi desain produk, uji coba I, revisi produk II, uji coba II, revisi produk akhir, serta diseminasi dan implementasi yang dapat dijelaskan sebagai berikut. 


\section{Analisis Kebutuhan dan Kajian Pustaka}

Langkah pertama adalah melakukan analisis kebutuhan dan kajian pustaka atau studi pendahuluan dengan melakukan pengumpulan informasi yang meliputi kajian pustaka atau studi literatur, dan persiapan laporan awal. Penelitian awal atau analisis kebutuhan sangat penting dilakukan guna memeroleh informasi awal untuk melakukan pengembangan. Hal ini dilakukan melalui pengamatan kelas untuk melihat kondisi riil di lapangan.

\section{Perencanaan}

Kegiatan yang dilakukan pada tahap perencanaan ini adalah menganalisis silabus, menentukan kompetensi dasar dan indikator pencapaian kompetensi. Analisis tujuan pembelajaran, dilakukan untuk hal apa saja yang ingin dicapai setelah dilaksanakannya pembelajaran. Dari kompetensi dasar dijabarkan menjadi indikator pencapaian, kemudian dirumuskan menjadi tujuan pembelajaran. Tujuan menjadi standar yang akan dicapai dalam proses penyajian pembelajaran secara keseluruhan. Menganalisis pembelajaran, bertujuan untuk menentukan langkah-langkah pembelajaran yang harus dilakukan, menyusun instrumen validasi dan subjek uji coba.

\section{Penyusunan Draf Awal Produk}

Langkah yang ketiga adalah menyusun draf awal produk pendidikan yang akan dikembangkan, berupa bahan ajar menulis cerpen dengan menerapkan model pembelajaran berbasis pengalaman (experiential learning) siswa kelas XI SMK. Mengembangkan produk awal yang meliputi penyiapan materi pembelajaran, prosedur/penyusunan buku pegangan, dan instrumen evaluasi.

\section{Uji Validasi Desain Produk}

Langkah yang keempat adalah uji validasi desain produk yang biasa juga disebut uji internal. Menurut Sugiyono (2017:45), uji internal berarti menguji rancangan berdasarkan pendapat para ahli dan praktisi. Instrumen validasi dalam penelitian ini berupa angket/kuesioner yang berisi penilaian kelayakan buku berdasarkan aspek materi, bahasa, penyajian, dan grafika.

\section{Revisi Desain Produk}

Setelah desain produk awal divalidasi dan diuji internal, selanjutnya adalah merevisi rancangan/desain. Revisi rancangan/desain bertujuan untuk meningkatkan kualitas produk. Peneliti memperbaiki draf awal produk sesuai dengan masukan dari validator dan praktisi.

\section{Uji Coba I}

Uji coba I (uji coba terbatas) dilaksanakan untuk menguji produk. Uji coba ini dilakukan untuk mendapatkan informasi mengenai kualitas bahan ajar cerpen yang dikembangkan dan untuk mengetahui kekurangan atau kelemahan bahan ajar yang dikembangkan.

\section{Revisi Produk II}

Revisi produk II merupakan revisi yang dilakukan berdasarkan hasil uji coba I atau uji coba terbatas. Revisi produk dilaksanakan berdasarkan kekurangan dan kelemahan yang ditemukan pada uji coba awal dan hasil wawancara dengan guru atau pakar yang berupa koreksi atau masukan, observasi, dan angket. Hal tersebut dimaksudkan untuk menghasilkan bahan ajar yang berkualitas.

\section{Uji Coba II}

Uji coba II dilakukan untuk menguji desain II. Uji coba II diamati oleh 1 orang guru untuk melihat keunggulan dan kelemahan produk bahan ajar menulis cerpen yang dikembangkan. Hasil 
pengamatan selama proses pembelajaran berupa penilaian keterlaksanaan RPP, aktivitas guru dan siswa, respons guru dan siswa, instrumen penilaian, dan wawancara.

\section{Revisi Produk Akhir}

Revisi produk akhir dilaksanakan berdasarkan kekurangan atau kelemahan yang ditemukan pada uji coba II dan hasil wawancara dengan guru yang berupa koreksi atau masukan, observasi, dan angket. Hal tersebut bertujuan untuk menghasilkan bahan ajar yang berkualitas.

\section{Diseminasi dan Implementasi}

Diseminasi dan implementasi merupakan langkah terakhir dari urutan penelitian dan pengembangan, yakni melaporkan hasil penelitian dalam pertemuan-pertemuan dan memproduksi secara massal. Dalam penelitian ini, peneliti sementara hanya mengembangkan di lingkup SMK Negeri 12 Samarinda.

\section{HASIL DAN PEMBAHASAN}

\section{Desain Pengembangan Bahan} Ajar

Dari hasil studi pendahuluan di SMK Negeri 12 Samarinda, bahwa siswa kesulitan dalam menemukan dan mengembangkan ide cerita. Sebagian siswa mengalami kejenuhan dalam belajar karena masih banyak guru yang menggunakan metode yang konvensional, yaitu ceramah dan buku yang digunakan juga terbatas sehingga siswa harus bergantian meminjam buku ke perpustakaan pada jam pelajaran dan harus mengembalikan buku tersebut setelah proses pembelajaran selesai. Isi buku secara keseluruhan sudah baik namun pada materi cerpen hanya menjelaskan materi dan tugas menulis cerpen tetapi tidak dijelaskan secara rinci bagaimana langkah-langkah dalam menulis agar siswa lebih mudah dalam memahami materi dan mengembangkan ide yang dimiliki menjadi teks cerpen.
Berdasarkan permasalahan tersebut, peneliti melakukan pengembangan bahan ajar dan memilih model pembelajaran berbasis pengalaman (experiential learning) karena kesesuaian model pembelajaran ini dengan materi pembelajaran menulis cerpen dan model ini belum pernah digunakan oleh guru dalam pengajaran menulis cerpen.

\section{Pelaksanaan Pembelajaran Berbasis Pengalaman Pelaksanaan pembelajaran \\ Pelaksanaan pembelajaran menulis} cerpen berbasis pengalaman siswa dilaksanakan di kelas XI Otomotif dan Kelas XI Akuntansi, SMK Negeri 12 Samarinda. Berdasarkan pelaksanaan pembelajaran, siswa antusias mengikuti proses pembelajaran. Siswa mengikuti pembelajaran dengan baik, tenang, dan mengikuti instruksi guru dengan tertib. Pelaksanaan pembelajaran ini menggunakan empat tahap model pembalajaran berbasis pengalaman (experiential learning), yaitu tahap pengalaman konkret, pengamatan reflektif, konseptualisasi abstrak, dan percobaan aktif.

\section{Kualitas Bahan Ajar Menulis Cerpen Berbasis Pengalaman Siswa Kelas XI SMK}

Kualitas bahan ajar diketahui dari hasil validasi, kepraktisan, dan keefektifan. Rekapitulasi hasil uji validasi, yakni nilai materi $90 \%$, nilai bahasa $88 \%$, nilai sajian $89 \%$, dan nilai grafika $90 \%$ yang diperoleh hasil rata-rata $90 \%$ dengan kriteria sangat valid yang diinterpretasikan dengan skala 86-100\% sehingga dikategorikan sangat layak. Dengan demikian, bahan ajar menulis cerpen berbasis pengalaman sangat layak digunakan oleh siswa Kelas XI semester ganjil untuk menunjang kegiatan pembelajaran.

Kepraktisan dilihat dari hasil penilaian keterlaksanaan RPP, respons guru, dan respons siswa. Keterlaksanaan 
RPP memperoleh hasil 92\% dengan kategori sangat terlaksana, respons guru memperoleh nilai $89 \%$ dengan kategori positif, dan respons siswa memperoleh nilai $87 \%$ yang diperoleh hasil rata-rata $89 \%$ dengan kriteria sangat praktis. Jika diinterpretasikan dengan skala $51-100 \%$ maka dikategorikan positif. Dengan demikian, bahan ajar menulis cerpen berbasis pengalaman siswa kelas XI SMK adalah sangat praktis untuk digunakan.

Keefektifan dilihat dari hasil penilaian aktivitas guru, aktivitas siswa, dan nilai menulis cerpen siswa. Aktivitas guru memperoleh hasil 93\% dengan kategori positif, aktivitas siswa memperoleh nilai 92\% dengan kategori positif, dan nilai menulis siswa secara keseluruhan memperoleh nilai $81 \%$, yaitu semua siswa tuntas yang diperoleh hasil rata-rata 89\% dengan kriteria sangat efektif. Jika diinterpretasikan dengan skala 86-100\% maka dikategorikan positif. Dengan demikian, bahan ajar menulis cerpen berbasis pengalaman siswa kelas XI SMK adalah sangat efektif untuk digunakan.

Dengan demikian dapat disimpulkan bahwa seluruh rekapitulasi desain akhir bahan ajar menulis cerpen berbasis pengalaman siswa Kelas XI adalah kevalidan (produk siap dipakai di lapangan tanpa revisi), keterlaksanaan rencana pelaksanaan pembelajaran (sangat sesuai, sangat jelas, sangat terlaksana, dan sangat operasional) dan reliabel respons guru dan siswa (sangat praktis), aktivitas guru (sangat praktis), aktivitas siswa (sangat baik), dan perbedaan hasil menulis cerpen siswa tanpa menggunakan bahan ajar dibandingkan dengan menggunakan bahan ajar sangat signifikan. Dengan demikian, maka bahan ajar menulis cerpen berbasis pengalaman siswa Kelas XI sangat valid, sangat praktis, dan sangat efektif.

\section{E. PENUTUP}

Berdasarkan hasil penelitian dan pengembangan bahan ajar menulis cerpen berbasis pengalaman siswa Kelas XI SMK ini dapat disimpulkan sebagai berikut. Menulis cerpen berbasis pengalaman siswa kelas XI SMK dalam penelitian ini menggunakan sepuluh langkah yang diadaptasi dari model Borg \& Gall, yaitu metode research and development $(\mathrm{R} \& \mathrm{D})$ sesuai dengan kebutuhan penelitian. Sepuluh langkah yang digunakan, yaitu analisis kebutuhan dan kajian pustaka, perencanaan, penyusunan draf awal produk, uji validasi desain produk, revisi desain produk, uji coba I, revisi desain II, uji coba II, revisi produk akhir, serta diseminasi dan implementasi. Penelitian ini dilakukan untuk mengembangkan bahan ajar menulis cerpen berbasis pengalaman siswa Kelas XI SMK dengan menggali kearifan lokal. Produk yang dihasilkan berupa bahan ajar buku pegangan siswa dan buku pegangan guru sebagai penunjang dalam menulis cerpen. Penelitian ini sangat perlu dilakukan sebagai bahan agar dapat meningkatkan kemampuan siswa dalam menulis cerpen dan membantu guru dalam mengelola pembelajaran yang praktis, efektif, serta dapat menjadi referensi dalam menyampaikan materi pelajaran menulis cerpen.

Kualitas bahan ajar ini diperoleh dari hasil uji kevalidan, hasil uji kepraktisan, dan hasil uji keefektifan. Hasil uji kevalidan memperoleh nilai rata-rata 90\% dengan kategori sangat valid, hasil uji kepraktisan memperoleh nilai rata-rata $89 \%$ dengan kriteria sangat praktis, dan hasil uji keefektifan memperoleh nilai ratarata $89 \%$ dengan kriteria sangat efektif. Dengan demikian, bahan ajar menulis cerpen berbasis pengalaman siswa Kelas $\mathrm{XI}$ adalah sangat valid, sangat praktis, dan sangat efektif.

\section{DAFTAR PUSTAKA}

Akhadiah, S., Arsjad, M. G., \& Ridwan, S. H. (1991). Pembinaan Kemampuan Menulis Bahasa Indonesia. Jakarta: Erlangga. 
Ariska, W. W. (2011). Kualitas Bahan Ajar dan Pemanfaatan Bahan Ajar Berupa Buku Paket di SMKN 2 Yogyakarta Mata Pelajaran Produktif Program Keahlian Teknik Instalasi Kelas X. Skripsi. Universitas Negeri Yogyakarta. Diperoleh dari http://eprints.uny.ac.id/23455/1/ Ariska $\% 20$ W $\% 20$ Widapratama $\% 20$ -\%2007501241013.pdf

Daryanto, \& Dwicahyono, A. (2014). Pengembangan Perangkat Pembelajaran (Silabus, RPP, PHB, dan Bahan Ajar). Yogyakarta: Gava Media.

Depdiknas. (1993). Kamus Besar Bahasa Indonesia (Edisi IV). Jakarta: Balai Pustaka.

Fathurrohman, M. (2015). Model-Model Pembelajaran Inovatif. Yogyakarta: ArRuzz Media.

Hamdani. (2010). Strategi Belajar Mengajar. Bandung: Pustaka Setia.

Jabrohim. (1994). Teori Penelitian Sastra. Yogyakarta: Masyarakat Poetika Indonesia dan IKIP Muhammadiyah Yogyakarta.

Keraf, G. (2016). Diksi dan Gaya Bahasa. Jakarta: Gramedia Pustaka Utama.

Kokasih, E. (2012). Dasar-Dasar Keterampilan Menulis. Bandung: Yrama Widya.

Kulsum, U., Hudiyono, Y., \& Sulistyowati, E. D. (2018). Pengembangan Bahan Ajar Menulis Cerpen dengan Media Storyboard pada Siswa Kelas X SMA. Diglosia: Jurnal Kajian Bahasa, Sastra, Dan Pengajarannya, 1(1), 1-12. Diperoleh dari http://jurnal.fkip.unmul.ac.id/inde x.php/diglosia/article/view/2

Lestari, I. (2013). Pengembangan Bahan Ajar Berbasis Kompetensi Sesuai dengan Kurikulum Satuan Tingkat Pendidikan. Padang: Akademia Permata.
Majid, A. (2013). Strategi Pembelajaran. Bandung: Remaja Rodas Karya.

Masruroh, A. (2015). Pengembangan Modul Pembelajaran Menulis Cerpen Berbasis Pengalaman (Experiential Learning) untuk Siswa SMP/MTs. Skripsi. Universitas Negeri Yogyakarta. Diperoleh dari http://journal.student.uny.ac.id/ojs /ojs/index.php/pbsi/article/view/ $1565 / 2752$

Moleong, L. J. (2012). Metodologi Penelitian Kualitatif. Bandung: Remaja Rosdakarya.

Muryanto, A. K. (2008). Aku Pandai Menulis Cerpen. Yogyakarta: Citra Aji Parama.

Musaba, Z., \& Siddik, M. (2017). DasarDasar Keterampilan Menulis. Yogyakarta: Aswaja Pressindo.

Nurgiyantoro, B. (1987). Penilaian dalam Pengajaran Bahasa dan Sastra. Yogyakarta: BPFE.

Nurgiyantoro, B. (2009). Teori Pengkajian Fiksi. Yogyakarta: Gadjah Mada University Press.

Nursisto. (2000). Penuntun Mengarang. Yogyakarta: Adicita Karya Nusa.

Prastowo, A. (2013). Panduan Kreatif Membuat Baban Ajar Inovatif, Menciptakan Metode Pembelajaran yang Menarik dan Menyenangkan. Yogyakarta: Diva Press.

Rampan, K. L. (2003). Riam. Yogyakarta: Gita Nagasari.

Rampan, K. L. (2009). Apresiasi Cerpen Indonesia Mutakhir. Jakarta: Buku Pop.

Roekhan. (1991). Menulis Kreatif: DasarDasar dan Petunjuk Penerapannya. Malang: Yayasan Asih Asah Asuh.

Rokhmansyah, A. (2014). Studi dan Pengkajian Sastra. Yogyakarta: Graha Ilmu. 
Rusman. (2016). Model-Model Pembelajaran: Mengembangkan Profesionalisme Guru. Jakarta: Rajagrafindo Persada.

Sanjaya, W. (2013). Strategi Pembelajaran Berorientasi Standar Proses Pendidikan). Jakarta: Prenada Media Grup.

Silberman, Mel. 2016. Handbook Experiential Learning. Strategi Pembelajaran dari Dunia Nyata. Bandung: Nusamedia.

Sofan, A. (2015). Implementasi Pembelajaran Aktif dalam Kurikulum 2013. Jakarta: Prestasi Pustaka Jakarta.
Sugiyono. (2015). Metode Penelitian dan Pengembangan (Research and Development). Bandung: Alfabeta.

Sugiyono. (2017). Metode Penelitian Pendidikan: Pendekatan Kuantitatif, Kualitatif, dan R\&D. Bandung: Alfabeta.

Tarigan, H. G. (2013). Menulis sebagai Suatu Keterampilan Berbahasa. Bandung: Angkasa. 